\title{
Protective effect of moringa-based beverages against hyperlipidemia and hyperglycemia in type 2 diabetes-induced rats
}

\author{
${ }^{1}$ Al Zhrani, M.M., ${ }^{1}$ Althwab, S.A., ${ }^{1}$ Aljutaily, T., ${ }^{1,2}$ Alfheeaid, H.A., ${ }^{1,3}$ Ashoush, I.S. and \\ $1,4, *$ Barakat, $\mathrm{H}$. \\ ${ }^{I}$ Department of Food Science and Human Nutrition, College of Agriculture and Veterinary Medicine, \\ Qassim University, 51452 Buraydah, Saudi Arabia \\ ${ }^{2}$ School of Medicine, Dentistry and Nursing, College of Medical, Veterinary and Life Sciences, University of \\ Glasgow, G12 8QQ, Glasgow, United Kingdom \\ ${ }^{3}$ Food Science Department, Faculty of Agriculture, Ain Shams University, Cairo, Egypt \\ ${ }^{4}$ Food Technology Department, Faculty of Agriculture, Benha University, 13736 Moshtohor, Qaliuobia, \\ Egypt
}

\begin{abstract}
Article history:
Received: 25 September 2020 Received in revised form: 27 October 2020

Accepted: 17 December 2020 Available Online: 28 March 2021
\end{abstract}

\section{Keywords:}

Moringa oleifera,

Functional beverages,

Lipid profile,

Glycemia,

Diabetes

DOI:

https://doi.org/10.26656/fr.2017.5(2).536

\begin{abstract}
The objectives of this study were to determine the phenolic profile and potential antioxidant activity of Moringa oleifera leaves (MOL) cultivated in Saudi Arabia and to investigate the protective effect of moringa-based beverages on lipidemic and glycemic parameters in alloxan-induced diabetic rats (DR). The total phenolic content (TPC), chlorophylls, total carotenoids, total flavonoids, total flavonols, ascorbic acid content, and antioxidant activities (AOA) of MOL were determined and HPLC analysis of MOL was quantitatively performed. Moringa beverages as pure moringa (PM) and ginger-flavored moringa (GM) were given to diabetic rats (DR) at a dose of $1 \mathrm{~mL} 100 \mathrm{~g}^{-1}$ body weight/day for a successive six weeks. Glucose level (GL), lipid profile, and antioxidant parameters including malondialdehyde (MDA), reduced glutathione (GSH), and pancreas histopathological alterations were examined. Results indicated that MOL and prepared moringa-based beverages possess a suppressive amount of phenolics with considerable antioxidant activity in vitro. TPC was $78.72 \mathrm{mg} \mathrm{GAE} \mathrm{g}^{-1} \mathrm{DW}$ possess AOA as $36.33 \mu \mathrm{mol}$ $\mathrm{TE}^{-1} \mathrm{DW}$. Among the eleven identified phenolic acids and six flavonoids in MOL, caffeic acid and catechin were predominant and recorded 151.01 and $736.30 \mathrm{mg} / 100 \mathrm{~g}$, respectively. Administration of PM or GM beverages significantly decreased GL and significantly improved serum lipid profiles in the DR group. Interestingly, oral administration of PM and GM beverages significantly attenuated the MDA and GSH levels in the DR compared to normal rats. Histopathologically, severe atrophy was noted in the islets of Langerhans in the DR group. However, after six weeks of oral administration of PM beverage, only mild atrophy was recorded in the islets of Langerhans, while with GM beverage, no histopathological alteration in the islets of Langerhans was found. The nutritional and biological evaluation of the moringa-based beverages revealed that both PM and GM beverages exhibit high antioxidant activity, possess antihyperglycemic and antihyperlipidemic effects, and alleviated alloxan-induced pancreatic damage in DR. Moringa could be recommended for diabetes and utilized for its great therapeutic benefits.
\end{abstract}

\section{Introduction}

Health concerns related to the ingestion of excessive calories involving high sugar consumption and association with diseases are considered critical issues by numerous organizations in the food industry (Weaver and Finke, 2003). A recent report on diabetes mellitus (DM) prevalence has indicated that the Kingdom of
Saudi Arabia (KSA) ranks second in the Middle East and seventh in the world (WHO, 2017). Recently, the hypolipidemic, hypoglycemic, and hepatoprotective effects of different parts of the M. oleifera plant have been investigated (Paula et al., 2017; Villarruel-López et al., 2018; Oboh et al., 2018; Balakrishnan et al., 2019). Moringa oleifera Lam, belonging to the Moringaceae family, is a rapidly growing perennial foliage tree that is 
widely planted because of its great adaptability to climatic conditions (Teixeira et al., 2014). It has been imported from the tropics to the sub-Himalayan regions, Latin America, Oceania, Africa, and tropical Asia (Fahey, 2005), and is successfully cultivated in KSA (Alaklabi, 2015; Mridha, 2015). Its nutritional, therapeutic, and prophylactic characteristics have resulted in $M$. oleifera being used as food, in medications, and for industrial purposes (Olayaki et al., 2015).

Moringa oleifera leaves (MOL) contain substantial amounts of vitamins and considerable quantities of proteins, minerals, and phytonutrients (Amaglo et al., 2010), as well as being a good source of total phenols (Hekmat et al., 2015), with high antioxidant capacities (Paula et al., 2017) for oral health care (Mohanty et al., 2020). High amounts of phytochemicals such as kaempferol and quercetin glycosides were identified as the main phenolic compounds (Leone et al., 2015). However, additional phenolics were characterized as gallic acid, syringic acid, quercetin 3-O-beta-glucoside, and rutin (Manguro and Lemmen, 2007). Many parts of the $M$. oleifera tree are recognized as being respectable sources of phenolic acids, flavonoids such as quercetin and kaempferol glucosides (Coppin et al., 2013; Leane et al., 2015), and glucosinolates (Amaglo et al., 2010), carotenoids (Saini et al., 2014a), polyunsaturated fatty acids (PUFAs), and folate (Saini et al., 2016), as well as highly bioavailable minerals (Saini et al., 2014b).

Another of the many therapeutic activities of $M$. oleifera is the reasonably high antioxidant capacity of its leaves, flowers, and seeds (Atawodi et al., 2010). The potential therapeutic significance of $M$. oleifera against diabetes, rheumatoid arthritis, cancer, and other diseases have been reported (Gopalakrishnan et al., 2016) as well as oxidative stress (Khalid et al., 2020). The biological activities of $M$. oleifera include antiatherosclerotic (Chumark et al., 2008), immune-boosting, antioxidant, and antimicrobial characteristics (Miyoshi et al., 2004), anti cardiovascular disease, antiviral (Khalafalla et al., 2010), and anti-inflammatory (Kumar Gupta et al., 2013) properties, as well as tumor-suppressive effects in hepatocarcinoma cancer, colon cancer, and myeloma (Khalafalla et al., 2010). Awodele et al. (2012) reported that the aqueous leaf extract of $M$. oleifera was safe when orally administered. Indeed, one goal in the KSA 2030 vision requires the updating of health-promoting research focusing on local and natural resources in particular. However, moringa is a newly cultivated plant in KSA (Alaklabi, 2015; Mridha, 2015) and research work concerned with it in the context of the rising incidence of $\mathrm{DM}$ is woefully inadequate (Abdulaziz $\mathrm{Al}$
Dawish et al., 2016). Therefore, the present study aimed to investigate the bioactive components and phenolic profile of the newly cultivated M. oleifera in Gazan, KSA. To this end, flavored moringa-based functional beverages were prepared, and chemically and nutritionally evaluated. Furthermore, the hypolipidemic and hypoglycemic effects of these moringa functional beverages were investigated via biochemical and histopathological approaches.

\section{Material and methods}

2.1 Collection of Moringa oleifera leaves and Zingiber officinale rhizomes

Ten kilograms of dried M. oleifera Lam. leaves harvested in 2017 were obtained from the Al Owed Organic Nadawy Farm, Gazan, KSA. The leaves were inspected and stems and twigs, as well as yellow leaves, were removed. After cleaning, the leaves were kept at $4 \pm 1^{\circ} \mathrm{C}$ until used. Fresh ginger (Z. officinale) rhizomes were purchased from local markets in Buraidah, Al Qassim Region, KSA. The rhizomes were cleaned and kept at $4 \pm 1^{\circ} \mathrm{C}$ until extracted and processed.

\subsection{Preparation of flavored moringa-based functional beverages and natural ginger distillate}

The dried MOL was ground using a laboratory-type knife mill (Christison, CA, USA), extracted in boiling water $(1: 10, \mathrm{w}: \mathrm{v})$ for $5 \mathrm{mins}$, and then immediately filtered through cheesecloth and divided into four lots. The first was divided into two portions. One of them was sweetened with sucralose (SU: BulkSupplements.com, 7511 Eastgate Road, Henderson, NV, USA) and formulated as pure moringa (PM) in a 3\% sucralose base $(\mathrm{PM}+\mathrm{SU})$. The second portion was kept as it was (PM). The second lot was flavored with $2 \%$ ginger distillate and then divided into two portions. One of them was sweetened with SU and formulated as ginger-moringa $(\mathrm{GM})$ in a $3 \%$ sucrose base $(\mathrm{GM}+\mathrm{SU})$ and the second was kept as it was (GM). The ginger distillate was prepared by thoroughly washing, cleaning, and slicing the ginger rhizomes (GR). The sliced ginger was mixed with water, boiled at $100^{\circ} \mathrm{C}$ for $10 \mathrm{~min}$, and then cooled and slurred in a commercial laboratory blender (Christison Laboratory Blender, CA, USA) at low speed $(18,000 \mathrm{rpm})$ for 2 mins. The slurry was filtered, steam distillation was carried out, and the distillate was collected and used as a natural ginger flavor.

\subsection{Ascorbic acid determination}

The ascorbic acid content in the dried MOL and moringa beverages was determined using the 2,6dichloro phenol indophenol titrimetric method. The 
ascorbic acid content was expressed as $\mathrm{mg} / 100 \mathrm{~g} \mathrm{dw}$ (Silva et al., 1999).

\subsection{Phytochemical analysis}

Total phenolic compound (TPC) content was determined using the Folin-Ciocalteau method and was expressed as milligram of gallic acid equivalents per gram of sample (mg GAE $100 \mathrm{~g}^{-1} \mathrm{dw}$ ) according to Bettaieb et al. (2010). Total carotenoid (TC) content was determined colorimetrically as described by Yuan et al. (2009). The antioxidant activity as DPPH radical scavenging activity (DPPH-RSA) was determined colorimetrically using the 2,2-diphenylpicrylhy-drazyl (DPPH) radical. The DPPH free radical inhibition percentage was calculated; results were interpreted by plotting for the Trolox standard curve and were presented as $\mu \mathrm{mol} \mathrm{TE} \mathrm{g}^{-1} \mathrm{dw}$ (Zhang and Hamauzu, 2004). Total flavonoids (TF) and total flavonols (TFL) contents were determined and results were presented as the mg quercetin equivalent (QE) $\mathrm{g}^{-1}$ using the method of Barakat and Ghazal (2016) and Kumaran and Karunakaran (2007), respectively.

\subsection{Fractionation of phenolic compounds in M. oleifera leaves by (HPLC-DAD)}

Defatted samples of moringa were dried in a hood at room temperature then extracted with $70 \% \mathrm{MeOH}$. The moringa extracts were evaporated under $\mathrm{N}$ stream and then resolved with absolute $\mathrm{MeOH}$ and analyzed using a liquid chromatography column (Agilent Technologies 1100 series) equipped with an autosampler and a diodearray detector (HPLC-DAD) (Kim et al., 2006). The analytical column (Agilent Eclipse XDB C18, $150 \times$ $4.6 \mathrm{~m} ; 5 \mathrm{~m}$, with a $\mathrm{C} 18$ guard column) used acetonitrile (solvent A) and $2 \%$ acetic acid in water ( $\mathrm{v} / \mathrm{v})$ (solvent $\mathrm{B})$ as the mobile phase. All samples were filtered through a $0.45-\mu \mathrm{m}$ Acrodisc syringe filter (Gelman Laboratory, MI, USA) before injection. The run was performed at a flow rate of $0.8 \mathrm{~mL} \mathrm{~min}{ }^{-1}$ for 70 mins, followed by 10 mins of post-run for reconditioning. Peaks were simultaneously monitored at 280,320, and $360 \mathrm{~nm}$. Phenolics were identified by congruent retention times and the UV spectrum, compared with known standards, and then integrated and calculated based on sample weight.

\subsection{Biological evaluation of moringa beverages against diabetes-induced in rats}

\subsubsection{Animals}

Male albino Wistar rats, weighing 150-180 g were housed at the Department of Food Science and Human Nutrition, College of Agriculture and Veterinary Medicine, Qassim University, KSA. The animals were allowed to become accustomed to the laboratory environment $\left(23 \pm 2^{\circ} \mathrm{C}\right.$ and $40-45 \%$ relative humidity) and the laboratory photoperiod cycle (12 hrs light: $12 \mathrm{hrs}$ dark) for 15 days. The rats had free access to tap water ad libitium. All rats received a commercial diet covering recommended nutrient requirements. The current experimental protocol was approved by the Qassim University Animal Ethics Committee and met the guidelines for the care and use of animals in scientific research.

\subsubsection{Experimental design and diabetes induction}

Immediately after acclimation, the rats were separated into four groups of ten each. The first group (negative control) received distilled water as the vehicle, while the other three groups were intraperitoneally injected for three successive days with freshly prepared alloxan monohydrate solution (PubChem CID: 5781) at a dose of $150 \mathrm{mg} \mathrm{kg}^{-1}$ bw. One-week post-injection, rats showing fasting blood glucose of more than $200 \mathrm{mg} \mathrm{dL}^{-1}$ were considered as diabetic rats (DR) and were then divided into three groups. Group 2 (positive control) was kept as a pathogenically diabetic. Groups 3 and 4 were given the PM and GM beverages, respectively, in corresponding doses according to their fortnight weight. Beverages were administered through oral gavage in doses of $1 \mathrm{~mL} / 100 \mathrm{~g} \mathrm{BW}$ per day for a successive six weeks. The calculation was based on the consumption of $275 \mathrm{~mL}$ day $^{-1}$ for a $70-\mathrm{kg}$ human, as similarly reported by Rouanet et al. (2010). The body weight of the rats was measured at the beginning of the experimental period and then weekly for up to 6 weeks. At the end of the experiment and after an overnight fast, the rats were anesthetized and blood samples were collected from the jugular veins and then centrifuged at $3000 \mathrm{rpm}$ for 30 mins to obtain blood serum, which was kept at $-20^{\circ} \mathrm{C}$ for biochemical analysis.

\subsubsection{Blood biochemical and some antioxidant markers.}

Glucose, triglycerides (TG), total cholesterol, and HDL-Cho were measured by commercially available kits. The LDL-Cho and VLDL-Cho were calculated according to Noda et al. (2000). Reduced glutathione (GSH) in the serum was estimated according to the method described by Beutler et al. (Beutler, 1963). The level of lipid peroxidation in the serum was determined by measuring malondialdehyde (MDA) formation at 534 $\mathrm{nm}$ using the thiobarbituric acid reactive substances (TBARS) method (Ohkawa et al., 1979).

\subsubsection{Histopathological examination.}

At the end of the experiment, the rats were anesthetized using diethyl ether, bled, and then sacrificed. Necropsy samples were taken from the 
pancreas of rats in the different groups and fixed in $10 \%$ formalin saline for $24 \mathrm{hrs}$. The fixed tissues were washed in cold saline buffer and gradually dehydrated using methyl, ethyl, and absolute ethyl alcohols. Specimens were prepared with xylene as a clearing agent and embedded into paraffin wax at $56^{\circ} \mathrm{C}$ for $24 \mathrm{hrs}$. The paraffin-beeswax tissue blocks were cut into 4-micronthick sections using a sledge microtome. The tissue sections were fixed on glass slides, deparaffinized, and stained with Hematoxylin and Eosin for routine examination using a light electric microscope as described by Suvarna et al. (2018). Severity scoring of the histopathological alterations in photo sections of pancreatic tissues in each group was diagnosed blindly by two histopathological scientists according to Suvarna et al. (2018).

\subsection{Statistical analysis}

The statistical analysis was carried out using the SPSS software package (ver. 19) and analysis of variance (ANOVA) was applied according to the experimental design. The significance level was set as 0.05 and the Duncan test was performed according to Steel et al. (1997).

\section{Results and discussion}

3.1 Phytochemicals and antioxidant capacity of $M$. oleifera leaves and ginger rhizomes

The data in Table 1 demonstrate the TPC and antioxidant activity of the MOL and GR. In addition, phytochemicals such as chlorophyll $a$ and $b, \mathrm{TC}, \mathrm{TF}$, and TFL, and antioxidant activity, as well as the ascorbic acid content of the MOL and GR are also given in Table 1. The TPC content was 78.72 and $388.3 \mathrm{mg} \mathrm{GAE} \mathrm{g}^{-1}$ $\mathrm{dw}$ in the MOL and GR, respectively. As Moringa is a green leafy plant, the chlorophyll content was higher than in the ginger. The chlorophyll $a$ content was 284.2 and $2.03 \mathrm{mg} \mathrm{g}^{-1} \mathrm{dw}$ in the MOL and GR, respectively. The chlorophyll $b$ content in the MOL and GR was higher than the chlorophyll $a$ content. In contrast, the carotenoid content was higher in the GR than in the MOL, at 17.19 and $25.31 \mathrm{mg} \mathrm{g}^{-1} \mathrm{dw}$. M. oleifera was confirmed as a rich source of carotenoids (Zhang and Hamauzu, 2004; Saini et al., 2014a; Saini et al., 2014b). Similar results were recorded for flavonoids, flavonols, and vitamin C (Table 1). The M. oleifera leaves contained high levels of flavonoids and flavonols, e.g., quercetin and kaempferol (Coppin et al., 2013; Amaglo et al., 2010). The DPPH-RSA results for the MOL and GR referring to the Trolox equivalent $\mathrm{g}^{-1}\left[\mu \mathrm{mol} \mathrm{TE} \mathrm{g}^{-1}\right]$ are given in the same table. The findings for antioxidant activity were 36.33 and $175.5 \mu \mathrm{mol} \mathrm{TE} \mathrm{g}{ }^{-1} \mathrm{dw}$ for MOL and GR, similar to previous reports (Naeem et al., 2012;
Leone et al., 2015). The results for TPC were higher and for antioxidant activity lower than those of Leone et al. (Leone et al., 2015). The ascorbic acid in the MOL was higher than in the GR. A higher ascorbic acid content was observed than that found in current research. This may have been a result of dehydration (Saini et al., 2014b). However, bioactive compound results, particularly for TPC, and antioxidant activity findings varied because of various factors (Naeem et al., 2012).

Table 1. Phytochemicals and antioxidant activity of $M$. oleifera leaves and ginger rhizomes

\begin{tabular}{|c|c|c|}
\hline \multirow{2}{*}{ Items } & \multicolumn{2}{|c|}{ Raw materials } \\
\hline & MOL & GR \\
\hline $\begin{array}{l}\text { Total phenolic compounds } \\
\left.\text { [mg GAE g }{ }^{-1} \mathrm{dw}\right]\end{array}$ & $78.72 \pm 5.74^{\mathrm{b}}$ & $388.3 \pm 13.59$ \\
\hline Chlorophyll $a\left[\mathrm{mg} \mathrm{g}^{-1 \mathrm{dw}}\right]$ & $248.2 \pm 7.60^{\mathrm{a}}$ & $2.05 \pm 0.05^{\mathrm{b}}$ \\
\hline Chlorophyll $b\left[\mathrm{mg} \mathrm{g}^{-1 \mathrm{dw}}\right]$ & $496.39 \pm 15.2^{\mathrm{a}}$ & $4.16 \pm 0.10^{\mathrm{b}}$ \\
\hline Carotenoids $\left[\mathrm{mg} \mathrm{g}^{-1 \mathrm{dw}}\right]$ & $17.19 \pm 1.05^{\mathrm{a}}$ & $25.31 \pm 0.25^{\mathrm{b}}$ \\
\hline Flavonoids [mg QE $\mathrm{g}^{-1 \mathrm{dw}}$ ] & $22.76 \pm 0.44^{\mathrm{b}}$ & $56.87 \pm 1.59^{\mathrm{a}}$ \\
\hline Flavonols [mg QE g ${ }^{-1 \mathrm{dw}}$ ] & $13.5 \pm 0.13^{b}$ & $49.1 \pm 4.71^{\mathrm{a}}$ \\
\hline $\begin{array}{l}\text { Antioxidant activity } \\
{\left[\mu \mathrm{mol} \mathrm{TE}^{-1 \mathrm{dw}}\right]}\end{array}$ & $36.33 \pm 1.62^{b}$ & $175.5 \pm 9.88^{\mathrm{a}}$ \\
\hline Ascorbic acid $\left[\mathrm{mg} / 100 \mathrm{~g}^{\mathrm{fw}}\right]$ & $175.14 \pm 5.66^{\mathrm{a}}$ & $60.15 \pm 2.78^{b}$ \\
\hline
\end{tabular}

MOL: M. oleifera leaves, GR: ginger rhizomes. Values are expressed as mean $\pm \mathrm{SD}$. Values with different superscript within the same row are significantly different $(P>0.05)$.

A high score for overall acceptability (based on color, odor, and bitter aftertaste) was recorded for the PM and GM beverages; however, the SU-sweetened beverages, in particular, were accepted at a confirmed higher rate than the unsweetened beverages (data not shown). The phytochemicals and antioxidant activity of the moringa (PM and $\mathrm{PM}+\mathrm{SU}$ ) and ginger-flavored moringa ( $\mathrm{GM}$ and $\mathrm{GM}+\mathrm{SU}$ ) beverages are given in Table 2. The TPC content in the moringa beverages ranged from a low of 2.54 to $3.23 \mathrm{mg}$ GAE $100 \mathrm{~mL}^{-1}$. A significant difference was found between the (GM and $\mathrm{GM}+\mathrm{SU})$ and (PM and $\mathrm{PM}+\mathrm{SU})$ beverages. The chlorophyll $a$ content was $36.39,34.34,32.05$, and 35.13 $\mathrm{mg} 100 \mathrm{~mL}^{-1}$ in the $\mathrm{PM}, \mathrm{PM}+\mathrm{SU}, \mathrm{GM}$, and $\mathrm{GM}+\mathrm{SU}$, respectively. There was no significant difference $(p>0.05)$ between the $\mathrm{PM}+\mathrm{SU}$ and $\mathrm{GM}+\mathrm{SU}$, while a significant difference $(\mathrm{p}<0.05)$ was found between the PM and GM. The chlorophyll $b$ content was 30.29, 27.74, 26.35, and $27.05 \mathrm{mg} 100 \mathrm{~mL}^{-1}$ in the PM, $\mathrm{PM}+\mathrm{SU}, \mathrm{GM}$, and $\mathrm{GM}+\mathrm{SU}$, respectively. In general, no significant difference $(p>0.05)$ in chlorophyll $b$ was found between the flavored and non-flavored moringa beverages. The carotenoid content was $0.39,0.34,0.33$ and $0.38 \mathrm{mg} 100 \mathrm{~mL}^{-1}$ in the PM, PM+SU, GM and $\mathrm{GM}+\mathrm{SU}$, respectively. Carotenoids were higher in the PM than in the GM, but no significant difference $(p>0.05)$ was seen between the $\mathrm{PM}+\mathrm{SU}$ and $\mathrm{GM}+\mathrm{SU}$; 
Table 2. Phytochemicals and antioxidant activity of pure moringa and ginger-flavored moringa beverages

\begin{tabular}{|c|c|c|c|c|}
\hline \multirow{2}{*}{ Items } & \multicolumn{4}{|c|}{ Prepared beverages } \\
\hline & PMB & $\mathrm{PM}+\mathrm{SU}$ & GM & $\mathrm{GM}+\mathrm{SU}$ \\
\hline Total phenolic compounds [mg GAE $100 \mathrm{~mL}^{-1}$ ] & $2.9 \pm 0.02^{\mathrm{bc}}$ & $2.54 \pm 0.11^{\mathrm{c}}$ & $3.23 \pm 0.11^{\mathrm{a}}$ & $2.61 \pm 0.13^{\mathrm{ab}}$ \\
\hline Chlorophyll $a$ [mg $\left.100 \mathrm{~mL}^{-1}\right]$ & $36.93 \pm 0.89^{\mathrm{a}}$ & $34.34 \pm 1.91^{\mathrm{ab}}$ & $32.05 \pm 1.03^{b}$ & $35.13 \pm 1.02^{\mathrm{ab}}$ \\
\hline Chlorophyll $b$ [mg $\left.100 \mathrm{~mL}^{-1}\right]$ & $30.29 \pm 0.58^{\mathrm{a}}$ & $27.74 \pm 1.87^{\mathrm{a}}$ & $26.35 \pm 1.13^{\mathrm{a}}$ & $27.05 \pm 0.70^{\mathrm{a}}$ \\
\hline Carotenoids [mg $100 \mathrm{~mL}^{-1}$ ] & $0.39 \pm 0.02^{\mathrm{a}}$ & $0.34 \pm 0.02^{\mathrm{ab}}$ & $0.33 \pm 0.02^{\mathrm{b}}$ & $0.38 \pm 0.01^{\mathrm{ab}}$ \\
\hline Flavonoids [mg QE $100 \mathrm{~mL}^{-1}$ ] & $0.94 \pm 0.05^{\mathrm{a}}$ & $0.85 \pm 0.02^{\mathrm{ab}}$ & $0.77 \pm 0.02^{b}$ & $0.77 \pm 0.03^{b}$ \\
\hline Flavonols [mg QE $100 \mathrm{~mL}^{-1}$ ] & $0.62 \pm 0.01^{\mathrm{a}}$ & $0.57 \pm 0.04^{\mathrm{a}}$ & $0.63 \pm 0.00^{\mathrm{a}}$ & $0.59 \pm 0.00^{\mathrm{a}}$ \\
\hline Antioxidant activity $\left[\mu \mathrm{mol} \mathrm{TE} 100 \mathrm{~mL}^{-1}\right]$ & $1.13 \pm 0.07^{\mathrm{b}}$ & $1.21 \pm 0.01^{\mathrm{b}}$ & $1.26 \pm 0.01^{\mathrm{ab}}$ & $1.25 \pm 0.04^{\mathrm{ab}}$ \\
\hline Ascorbic acid [mg $\left.100 \mathrm{~mL}^{-1}\right]$ & $1.52 \pm 0.05^{\mathrm{ab}}$ & $1.34 \pm 0.05^{\mathrm{b}}$ & $1.59 \pm 0.05^{\mathrm{a}}$ & $1.50 \pm 0.07^{\mathrm{ab}}$ \\
\hline
\end{tabular}

PM: pure moringa beverages, PM+SU: pure moringa beverages sweetened with sucralose in 3\% sucrose base, GM: gingerflavored moringa beverages, GM+SU: ginger-flavored moringa beverages sweetened with sucralose in 3\% sucrose base . Values are expressed as mean \pm SD. Values with different superscript within the same row are significantly different $(P>0.05)$.

however, a significant difference between the PM and GM was noted. The added ginger extract in the GM may have caused a slight dilution in the carotenoid content. The flavonoid content was $0.94,0.85,0.77$, and $0.77 \mathrm{mg}$ QE $100 \mathrm{~mL}^{-1}$ in the $\mathrm{PM}, \mathrm{PM}+\mathrm{SU}, \mathrm{GM}$, and $\mathrm{GM}+\mathrm{SU}$, respectively. A significant difference $(p<0.05)$ was found between the PM and GM. In contrast, the flavonol content was $0.62,0.57,0.63$, and $0.59 \mathrm{mg}$ QE $100 \mathrm{~mL}^{-1}$ in the $\mathrm{PM}, \mathrm{PM}+\mathrm{SU}, \mathrm{GM}$, and $\mathrm{GM}+\mathrm{SU}$, respectively. No significant difference $(\mathrm{p}>0.05)$ in flavonol content was observed among the prepared moringa beverages (Table 2 ). The antioxidant activity values were $1.13,1.21,1.26$, and $1.25 \mu \mathrm{mol} \mathrm{TE} 100 \mathrm{~mL}^{-1}$ in the PM, PM+SU, GM, and $\mathrm{GM}+\mathrm{SU}$, respectively. There was no obvious significant difference $(p>0.05)$ among all the prepared beverages. The vitamin $\mathrm{C}$ values were 1.52, 1.34, 1.59, and $1.50 \mathrm{mg} 100 \mathrm{~mL}^{-1}$ in the $\mathrm{PM}, \mathrm{PM}+\mathrm{SU}, \mathrm{GM}$, and $\mathrm{GM}+\mathrm{SU}$, respectively. Interestingly, manufacturing such products would present beverages with valuable bioactive contents that could provide various functional features. The raw moringa and ginger content was retained and was determinable in the beverages. These findings are closely in accordance with those of Manguro et al. (2015), Zhang et al.(2004), and are confirmed by Badejo et al. (2014).

\subsection{Phenolic compound fractionation of Moringa oleifera leaves}

The data in Table 3 illustrates the simultaneous HPLC quantitative analysis of the phenolic compounds $(\mathrm{mg} / 100 \mathrm{~g})$ of MOL as the main component of the prepared beverages. The phenolic compounds were analyzed via HPLC and showed that MOL is rich in phenolic compounds. Twenty-two standards were applied for the potential occurrence of phenolics in methanolic extracts of MOL. Seventeen phenolic compounds were identified in the MOL extract. Among the eleven phenolic acids, caffeic was the predominant phenolic acid in the MOL extract at a high concentration of $151.01 \mathrm{mg} / 100 \mathrm{~g}$, while rosmarinic acid was the lowest (Table 3 ). The protocatechuic, $p$-hydroxybenzoic, gentisic, syringic, vanilic, ferulic, sinapic, $p$-coumaric, and cinnamic were $4.91,19.86,6.97,3.12,3.33,7.68$, $0.78,1.77$, and $1.79 \mathrm{mg} / 100 \mathrm{~g}$, respectively. Among the six flavonoids, catechin was represented at a high concentration of $736.30 \mathrm{mg} / 100 \mathrm{~g}$, followed by luteolin at $348.85 \mathrm{mg} / 100 \mathrm{~g}$, and rutin at $42.35 \mathrm{mg} / 100 \mathrm{~g}$. The obtained phenolic profile showed mixed results as the effects on phenolics were based on various factors (Naeem et al., 2012). Indeed, many studies have been concerned with the diversity of the phenolic profile and related antioxidant activities of MOL (Kim et al., 2006; Manguro and Lemmen, 2007; Saini et al., 2014a; Leone et al., 2015).

Table 3. Quantification analysis of phenolic compounds in $M$. oleifera leaves using HPLC-DAD

\begin{tabular}{lcc}
\hline Compound ${ }^{*}$ & Retention time & $\mathrm{mg} 100 \mathrm{~g}^{-1 \mathrm{DW}}$ \\
\hline Phenolic acids & 7.59 & 4.91 \\
\hline Protocatechuic & 11.00 & 19.86 \\
p-hydroxybenzoic & 11.84 & 6.97 \\
Gentisic & 14.54 & 151.01 \\
Caffeic & 15.39 & 3.12 \\
Syringic & 17.19 & 3.33 \\
Vanillic & 26.44 & 7.68 \\
Ferulic & 28.28 & 0.78 \\
Sinapic & 32.58 & 1.77 \\
p-coumaric & 38.01 & 0.42 \\
Rosmarinic & 41.33 & 1.79 \\
Cinnamic & & \\
\hline Flavonoids & 12.60 & 736.30 \\
\hline Catechin & 30.87 & 42.35 \\
Rutin & 36.83 & 1.09 \\
Apigenin-7-glucoside & 44.88 & 348.85 \\
Luteolin & 48.16 & 0.85 \\
Apigenin & 48.76 & 2.25 \\
Kaempferol &
\end{tabular}

* Phenolic acids and their derivatives were detected at 280 $320 \mathrm{~nm}$. Flavonoids were detected at $360 \mathrm{~nm}$. DW: Dry Weight. 
3.3 Effect of oral administration of Moringa olefiera beverages on weight gain of diabetic rats

Figure 1 demonstrates the effect of the oral administration of PM and GM beverages on the weight gain percentage of diabetic rats (DR). After one week, the weight gain percentage ranged from $8.95 \%$ in the $\mathrm{DR}$ to $17.54 \%$ in the normal rats (NR). A significant difference was found between the NR and the DR, $\mathrm{DR}+\mathrm{PM}$, and $\mathrm{DR}+\mathrm{GM}$ for up to 6 weeks. Administration of PM or GM beverages to the DR significantly improved their weight gain results. Regarding the mean period, there was a significant difference $(p<0.05)$ between the NR and the treated rats. No significant difference was noted between $\mathrm{DR}+\mathrm{PM}$ and $\mathrm{DR}+\mathrm{GM}$, which both differed significantly from the NR group. These results showed a similar trend more or less related to the results obtained by Olayaki et al. (2015), Toma et al. (2015), and Balakrishnan et al. (2018).

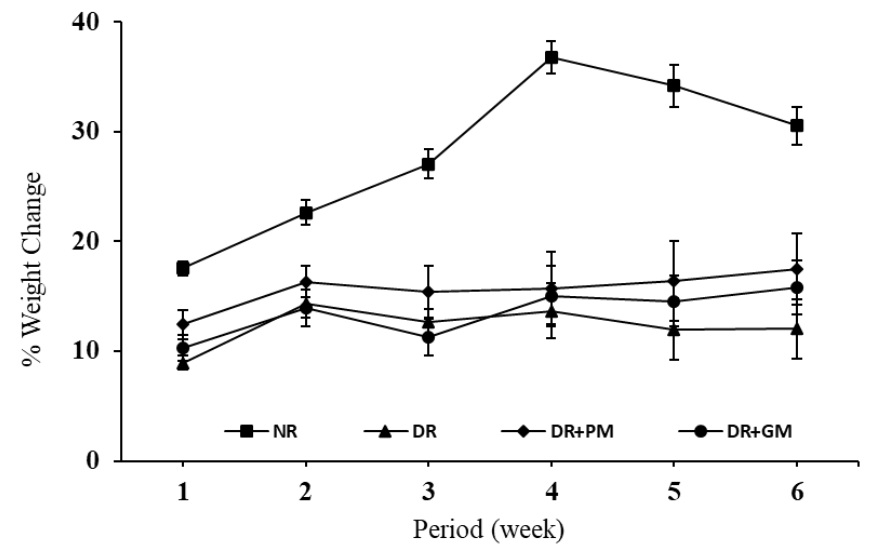

Figure 1. Effect of oral administration of moringa beverages on weight gain percentage of diabetic rats. NR: normal rats (negative control), DR: diabetic rats (alloxan-injected), DR+PM: diabetic rats administrated moringa, DR+GM: diabetic rats administrated ginger-flavored moringa.

\subsection{Effect of oral administration of Moringa olefiera beverages on the lipid profile of diabetic rats.}

Table 4 illustrates the effect of oral administration of moringa beverages on the lipid profiles including triglycerides, total cholesterol, HDL-Cho, LDL-Cho, and VLDL-Cho of the DR. The triglycerides ranged from
$40.67 \mathrm{mg} \mathrm{dL}^{-1}$ in the NR to $83.67 \mathrm{mg} \mathrm{dL}^{-1}$ in the DR. As a complication of diabetes, the triglycerides increased significantly (Tuorkey, 2016; Villarruel-López et al., 2018). A significant difference $(p<0.05)$ was found between the DR and the NR, DR+PM, and DR+GM. The total cholesterol ranged from $59.67 \mathrm{mg} \mathrm{dL}^{-1}$ in the NR to $77.33 \mathrm{mg} \mathrm{dL}^{-1}$ in the DR, whereas, because of the alloxan injections, increases in total cholesterol were noted after 6 weeks. Administration of PM reduced the total cholesterol, whereas the GM treatment was much better, and resulted in only a non-significant difference between the DR and the NR groups. A significant difference $(p<0.05)$ in the HDL-Cho content was seen between the non-treated and treated DR rats. Diabetes induction reduced the HDL-Cho significantly (Table 4). However, the LDL-Cho was represented by a high value in the DR group, which differed significantly $(p<0.05)$ from the NR group. A significant reduction of the LDLCho level in the moringa-treated groups was observed. In the same context, compared to the treated groups, the VLDL-Cho in the DR increased significantly $(p<0.05)$. There was no significant difference $(p<0.05)$ in the VLDL-Cho level among the moringa-treated groups and the NR. These results showed a trend similar to that seen in the results obtained by Olayaki et al. (2015), Tang et al. (2017), Balakrishnan et al. (2018), Villarruel-López et al. (2018), and Toma et al. (2015).

\subsection{Effect of oral administration of Moringa olefiera beverages on glucose level, MDA, and GSH of diabetic rats.}

The data in Table 5 and Figure 2 demonstrate the effect of the oral administration of moringa beverages on glucose levels and MDA and GSH contents in the serum of the diabetic rats. Over the 6 weeks, the fasting glucose level showed a higher value in the DR group when compared to the NR group. Administration of PM and GM decreased the glucose level significantly, approaching very close to that of the NR group. These results showed a trend similar to other findings obtained recently (Chumark et al., 2008; Paula et al., 2017).

As an oxidation indicator, MDA was determined in

Table 4. Effect of oral administration of moringa beverages for 6 weeks on the lipid profile of diabetic rats $(n=10)$

\begin{tabular}{lccccc}
\hline \multirow{2}{*}{ Treatment } & \multicolumn{5}{c}{ Parameters $\left(\mathrm{mg} \mathrm{dL}^{-1}\right)$} \\
\cline { 2 - 6 } & Triglycerides & Total Cholesterol & HDL-Cho & LDL-Cho & VLDL-Cho \\
\hline NR & $40.67 \pm 4.81^{\mathrm{a}}$ & $59.67 \pm 3.28^{\mathrm{b}}$ & $33.33 \pm 2.88^{\mathrm{a}}$ & $18.20 \pm 0.78^{\mathrm{c}}$ & $8.13 \pm 0.96^{\mathrm{b}}$ \\
$\mathrm{DR}$ & $83.67 \pm 5.43^{\mathrm{b}}$ & $77.33 \pm 7.06^{\mathrm{a}}$ & $22.03 \pm 4.25^{\mathrm{b}}$ & $40.57 \pm 2.49^{\mathrm{a}}$ & $14.73 \pm 1.09^{\mathrm{a}}$ \\
$\mathrm{DR}+\mathrm{PM}$ & $43.17 \pm 4.96^{\mathrm{a}}$ & $71.73 \pm 5.51^{\mathrm{a}}$ & $34.17 \pm 2.90^{\mathrm{a}}$ & $28.93 \pm 3.83^{\mathrm{b}}$ & $8.63 \pm 0.99^{\mathrm{b}}$ \\
$\mathrm{DR}+\mathrm{GM}$ & $44.67 \pm 4.75^{\mathrm{a}}$ & $64.96 \pm 4.29^{\mathrm{ab}}$ & $30.01 \pm 3.20^{\mathrm{a}}$ & $26.03 \pm 1.88^{\mathrm{b}}$ & $8.93 \pm 0.95^{\mathrm{b}}$ \\
\hline
\end{tabular}

NR: normal rats (negative control), DR: diabetic rats (alloxan-injected), DR+PM: diabetic rats administrated moringa, DR $+\mathrm{GM}$ : diabetic rats administrated ginger-flavored moringa . Values are expressed as mean \pm SD. Values with different superscript within the same row are significantly different $(P>0.05)$. 
all groups (Table 5). The data indicated that the MDA level was significantly higher in the DR group than in the NR group, which confirms the diabetes complications. Subsequently, the alloxan injection decreased the GSH significantly, up to $10.04 \mu \mathrm{mol} \mathrm{L} \mathrm{L}^{-1}$ in the DR group, compared to $23.07 \mu \mathrm{mol} \mathrm{L}^{-1}$ in the NR. Oxidative stress is known to be associated with diabetes and its complications (Jaiswal et al., 2013). In the present study, compared to the NR, a significant increase in the MDA level was observed as a biomarker of oxidative stress in the serum of the alloxan-induced DR. Lipid peroxidation is harmed by MDA, which is a component capable of eliciting much damage to the body and brain (Long et al., 2009). In this study, the MDA level increased and the GSH level concomitantly decreased in the DR group because of the induction. Administration of PM and GM decreased the MDA significantly compared with both the NR and DR groups. In the same context, the administration of PM and GM raised the GSH significantly in the $\mathrm{DR}+\mathrm{PM}$ and $\mathrm{DR}+\mathrm{GM}$ groups. Our findings revealed that moringa beverages improved the

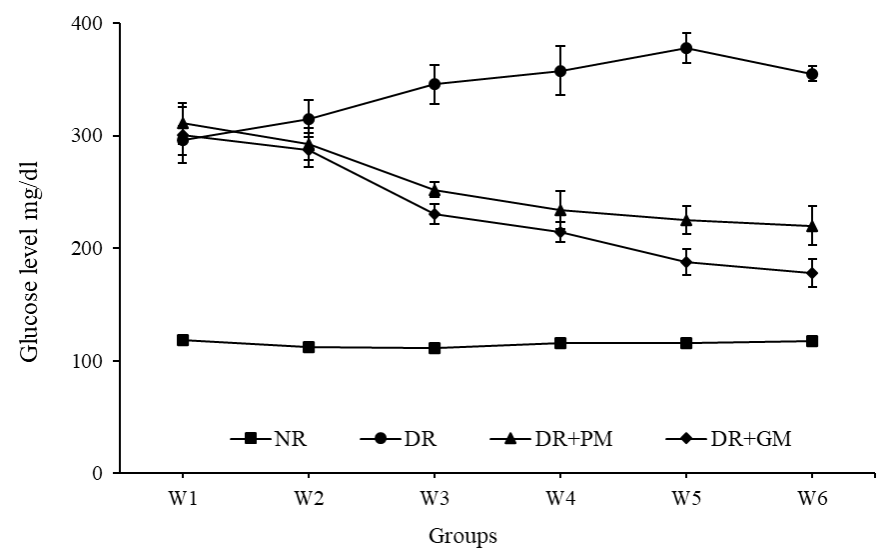

Figure 2. Effect of oral administration of moringa beverages for 6 weeks on non-fasting glucose level in blood during the experiment. NR: normal rats (negative control), DR: diabetic rats (alloxan-injected), DR+PM: diabetic rats administrated moringa, $\mathrm{DR}+\mathrm{GM}$ : diabetic rats administrated ginger-flavored moringa.

Table 5. Effect of oral administration of moringa beverages for 6 weeks on fasting glucose, MDA, and GSH profile of diabetic rats $(\mathrm{n}=10)$

\begin{tabular}{lccc}
\hline Treatment & $\begin{array}{c}\text { Glucose } \\
\left(\mathrm{mg} \mathrm{dL}^{-1}\right)\end{array}$ & $\begin{array}{c}\text { MDA } \\
\left(\mathrm{nmol} \mathrm{mL}^{-1}\right)\end{array}$ & $\begin{array}{c}\mathrm{GSH} \\
\left.(\mu \mathrm{mol} \mathrm{L})^{-1}\right)\end{array}$ \\
\hline NR & $60.67 \pm 4.17^{\mathrm{c}}$ & $0.18 \pm 0.01^{\mathrm{d}}$ & $23.07 \pm 0.64^{\mathrm{a}}$ \\
$\mathrm{DR}$ & $152.17 \pm 13.10^{\mathrm{a}}$ & $0.51 \pm 0.01^{\mathrm{a}}$ & $10.04 \pm 0.28^{\mathrm{d}}$ \\
$\mathrm{DR}+\mathrm{PM}$ & $89.83 \pm 11.31^{\mathrm{b}}$ & $0.36 \pm 0.01^{\mathrm{b}}$ & $16.77 \pm 0.58^{\mathrm{c}}$ \\
DR+GM & $79.55 \pm 12.44^{\mathrm{b}}$ & $0.24 \pm 0.02^{\mathrm{c}}$ & $20.61 \pm 0.47^{\mathrm{b}}$ \\
\hline
\end{tabular}

NR: normal rats (negative control), DR: diabetic rats (alloxaninjected), DR+PM: diabetic rats administrated moringa, DR+GM: diabetic rats administrated ginger-flavored moringa. Values are expressed as mean \pm SD. Values with different superscript within the same row are significantly different $(P>0.05)$. antioxidant status through modulation of the MDA level, antioxidant enzyme activities, and an increase in the GSH level (Jaiswal et al., 2013; Tang et al., 2017; Balakrishnan et al., 2019) which can be attributed to the phenolic compounds and especially to the higher content of caffeic, catechin, luteolin, and rutin (Table 3). Phenolics are sturdy antioxidants that possess considerable active radical scavenging ability and quench singlet oxygen, as well as activating antioxidant enzymes. The observed improvement in the enzymatic and non-enzymatic antioxidant defense systems exhibited by the PM and GM beverages could protect the body from oxidative stress. These results are similar in trend to the results attained by Tang et al. (2017), Oboh et al. (2018), and Balakrishnan et al. (2019).

3.6 Histopathological alterations in the pancreas of normal and alloxan-induced diabetic rats after treatment with moringa beverages

The histopathological findings of the pancreas in normal (negative control) and diabetic rats treated by moringa beverages are presented in Figure 3, I-IV. No histological alteration was observed and the regular histological structures of the endocrine islets of Langerhans as well as the exocrine acini are illustrated in Figure 3 I. However, severe atrophy can be noticed in the islets of Langerhans as shown in Figure 3, II. This histoarchitectural study of the pancreas in alloxan-induced diabetic rats displays a decrease in the volume of the islets, vast necrotic changes, damaged $\beta$-cell populations, fibrosis, and atrophy (Toma et al., 2015; Omodanisi et

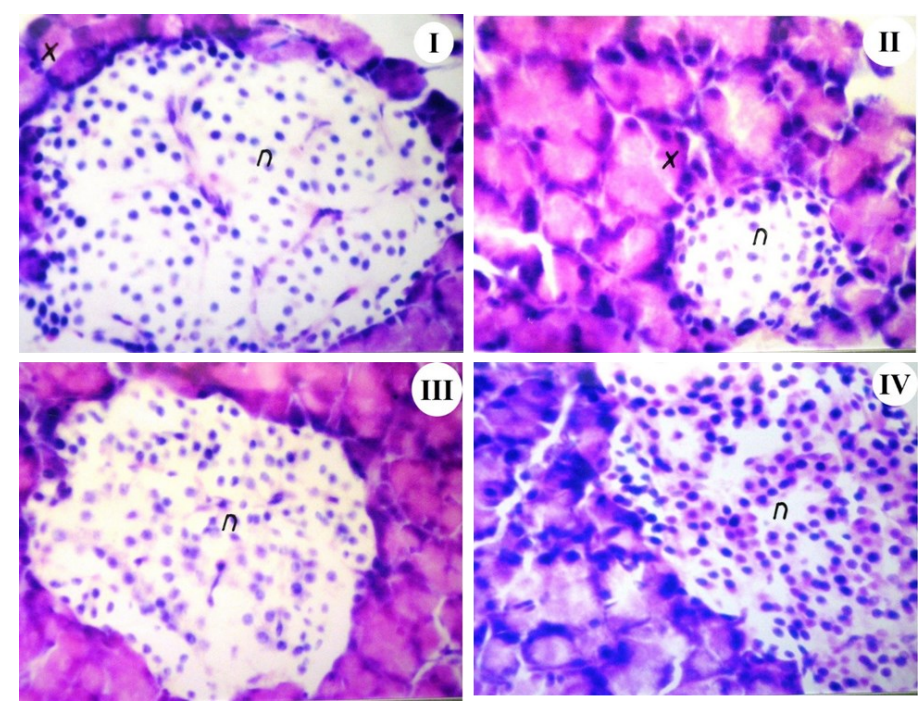

Figure 3. The histopathological findings of experimental groups: (I) No histopathological alteration was observed and normal histological structures of the endocrine islets of Langerhans as well as the exocrine acini were recorded, $\mathrm{x}=$ 100 , (II) Sever atrophy was seen in the islets of Langerhans with vast necrotic changes and remarkable fibrosis, $x=100$, (III) A mild atrophy was seen in the islets of Langerhans, $\mathrm{x}=$ 100, (IV) No histopathological alteration was observed in the islets of Langerhans, $\mathrm{x}=100$. 
Table 6. Severity scoring of the histopathological alterations in pancreatic tissues of normal and Alloxan-induced diabetes and treated diabetic rats with PM and GM after 6 weeks $(n=10)$

\begin{tabular}{lcccc}
\hline \multirow{2}{*}{ Alteration items } & \multicolumn{4}{c}{ Experimental groups } \\
\cline { 2 - 5 } & $\mathrm{NR}$ & $\mathrm{DR}$ & $\mathrm{DR}+\mathrm{PM}$ & $\mathrm{DR}+\mathrm{GM}$ \\
\hline Atrophy of islands of Langerhans & - & +++ & + & - \\
Absence of Langerhans cells & - & +++ & - & - \\
Ductal hyperplasia & - & ++ & - & - \\
\hline
\end{tabular}

$+++=$ Sever, $++=$ Moderate, $+=$ Mild, $-=$ Nil. NR: Normal rats, DR: Alloxan-diabetic rats, DR + PM: Diabetic rats + PM beverage and DR+GM: Diabetic rats + GM beverage.

al., 2017). With oral administration of PM for 6 weeks, mild atrophy in the islets of Langerhans can be observed (Figure 3, III). The PM attenuated the fibrotic and necrotic alterations and improved the number and size of the islets. Interestingly, with the administration of the GM beverage, no histopathological alteration was revealed in the islets of Langerhans, as recorded in Figure 3, IV. The severity scoring of the histopathological alterations in the pancreatic tissues of all experimental groups is given in Table 6 . The attained results were in agreement with those of Tang et al. (2017), Oboh et al. (2018), Balakrishnan et al. (2019), and Toma et al. (2015).

\section{Conclusion}

People usually select beverages based on several features. Under the circumstance of illness, the health impact is considered when choosing beverages. To attenuate the buildup of oxidative stress in the body, attention needs to be given to plant-based foods, especially those that are grossly underutilized. In conclusion, the present study confirmed that the moringa plant is rich in TPC with highly relevant antioxidant activities. Interestingly, oral administration of PM and GM beverages significantly reduced the blood glucose level and improved the lipid profile in alloxan-induced diabetic rats. These properties validate the possible useful effects of $M$. oleifera consumption in diabetes and encourage further studies to gain an understanding of its relevant mechanisms of action as an antidiabetic agent. Indeed, moringa has recently been cultivated in KSA, and more studies on moringa and its products are needed. Functional beverages containing MOL extracts mixed with GR are laden with antioxidative and antidiabetic potential. The consumption of these beverages in different forms should be encouraged.

\section{Conflict of interests}

The authors declare no competing interests.

\section{References}

Abdulaziz Al Dawish, M. Robert, A.A., Braham, R., Abdallah Al Hayek, A., Al Saeed, A., Ahmed Ahmed R. and Al Sabaan, F.S. (2016). Diabetes mellitus in Saudi Arabia: a review of the recent literature. Current Diabetes Reviews, 12(4), 359-368. https://

doi.org/10.2174/1573399811666150724095130

Alaklabi, A. (2015). Genetic diversity of Moringa peregrina species in Saudi Arabia with ITS sequences. Saudi Journal of Biological Sciences, 22 (2), 186-190. https://doi.org/10.1016/ j.sjbs.2014.09.015

Amaglo, N.K., Bennett, R.N.,. Curto, R.B.L, Rosa, E.A., Turco, V.L., Giuffrida, A., Curto, A.L., Crea F. and Timpo, G.M. (2010). Profiling selected phytochemicals and nutrients in different tissues of the multipurpose tree Moringa oleifera L., grown in Ghana. Food Chemistry, 122(4), 1047-1054. https:// doi.org/10.1016/j.foodchem.2010.03.073

Atawodi, S.E., Atawodi, J.C., Idakwo, G.A., Pfundstein, B., Haubner, R., Wurtele, G., Bartsch, H. and Owen, R.W. (2010). Evaluation of the polyphenol content and antioxidant properties of methanol extracts of the leaves, stem, and root barks of Moringa oleifera Lam. Journal of Medicinal Food, 13, 710-716. https://doi.org/10.1089/jmf.2009.0057

Awodele, O., Oreagba, I.A., Odoma, S., da Silva, J.A.T. and Osunkalu, V.O. (2012). Toxicological evaluation of the aqueous leaf extract of Moringa oleifera Lam. (Moringaceae). Journal of Ethnopharmacology, 139 (2), 330-336. https://doi.org/10.1016/ j.jep.2011.10.008

Badejo, A.A., Damilare, A. and Ojuade, T.D. (2014). Processing effects on the antioxidant activities of beverage blends developed from Cyperus esculentus, Hibiscus sabdariffa, and Moringa oleifera Extracts. Preventive Nutrition and Food Science, 19, 227-233. https://doi.org/10.3746/pnf.2014.19.3.227

Balakrishnan, B.B., Krishnasamy, K. and Choi, K.C. (2018). Moringa concanensis Nimmo ameliorates hyperglycemia in 3T3-L1 adipocytes by upregulating PPAR- $\gamma$, C/EBP- $\alpha$ via Akt signaling pathway and STZ-induced diabetic rats. Biomed Pharmacother, 103, 719-728. https://doi.org/10.1016/ j.biopha.2018.04.047

Balakrishnan, B.B., Krishnasamy, K., Mayakrishnan, V. and Selvaraj, A. (2019). Moringa concanensis 
Nimmo extracts ameliorates hyperglycemiamediated oxidative stress and upregulates PPARgamma and GLUT4 gene expression in liver and pancreas of streptozotocin-nicotinamide induced diabetic rats. Biomed Pharmacother, 112, 108688. https://doi.org/10.1016/j.biopha.2019.108688

Barakat, H. and Ghazal, G.A. (2016). Physicochemical properties of Moringa oleifera seeds and their edible oil cultivated at different regions in Egypt. Food and Nutrition Sciences, 7, 472-484. https:// doi.org/10.4236/fns.2016.76049

Bettaieb, I., Bourgou, S., Wannes, W.A., Hamrouni, I., Limam, F. and Marzouk, B. (2010). Essential oils, phenolics, and antioxidant activities of different parts of cumin (Cuminum cyminum L.). Journal of Agricultural and Food Chemistry, 58, 10410-10418. https://doi.org/10.1021/jf102248j

Beutler, E. (1963). Improved method for the determination of blood glutathione. Journal of Laboratory and Clinical Medicine, 61, 882-888.

Chumark, P., Khunawat, P., Sanvarinda, Y., Phornchirasilp, S., Morales, N.P., Phivthong-ngam, L.P., Ratanachamnong, Srisawat, S. and Klai-upsorn, S.P. (2008). The in vitro and ex vivo antioxidant properties, hypolipidaemic and antiatherosclerotic activities of water extract of Moringa oleifera Lam. leaves. Journal of Ethnopharmacology, 116(3), 439446. https://doi.org/10.1016/j.jep.2007.12.010

Coppin, J.P., Xu, Y., Chen, H., Pan, M.-H., Ho, C.-T., Juliani, R., Simon, J.E. and $\mathrm{Wu}$, Q. (2013). Determination of flavonoids by LC/MS and antiinflammatory activity in Moringa oleifera. Journal of Functional Foods, 5(4), 1892-1899. https:// doi.org/10.1016/j.jff.2013.09.010

Fahey, J.W. (2005). Moringa oleifera: A review of the medical evidence for its nutritional, therapeutic, and prophylactic properties. Part 1. Trees for Life Journal, 1, 21205-22185.

Gopalakrishnan, L., Doriya, K. and Kumar, D.S. (2016). Moringa oleifera: A review on nutritive importance and its medicinal application. Food Science and Human Wellness, 5(2), 49-56. https:// doi.org/10.1016/j.fshw.2016.04.001

Hekmat, S., Morgan, K., Soltani, M. and Gough, R. (2015). Sensory evaluation of locally-grown fruit purees and inulin fibre on probiotic yogurt in mwanza, Tanzania and the microbial analysis of probiotic yogurt fortified with Moringa oleifera. Journal of Health, Population and Nutrition, 33, 60 $-67$.

Jaiswal, D., Rai, P.K., Mehta, S., Chatterji, S., Shukla, S., Rai, D.K., Sharma, G., Sharma, B. and Watal, G.
(2013). Role of Moringa oleifera in regulation of diabetes-induced oxidative stress. Asian Pacific Journal of Tropical Medicine, 6(6), 426-432. https:// doi.org/10.1016/S1995-7645(13)60068-1

Khalafalla, M.M., Abdellatef, E., Dafalla, H.M., Nassrallah, A.A., Aboul-Enein, K.M., Lightfoot, D.A., El-Deeb, F.E. and El-Shemy, H.A. (2010). Active principle from Moringa oleifera Lam leaves effective against two leukemias and a hepatocarcinoma. African Journal of Biotechnology, 9, 8467-8471.

Khalid, A.R., Yasoob, T.B., Zhang, Z., Yu, D., Feng, J., Zhu, X. and Hang, S. (2020). Supplementation of Moringa oleifera leaf powder orally improved productive performance by enhancing the intestinal health in rabbits under chronic heat stress. Journal of Thermal Biology, 93, 102680. https:// doi.org/10.1016/j.jtherbio.2020.102680

Kim, K.-H., Tsao, R., Yang, R. and Cui, S.W. (2006). Phenolic acid profiles and antioxidant activities of wheat bran extracts and the effect of hydrolysis conditions. Food Chemistry, 95(3), 466-473. https:// doi.org/10.1016/j.foodchem.2005.01.032

Kumar Gupta, S., Kumar, B., Srinivasan, B., Nag, T.C., Srivastava, S., Saxena, R. and Aggarwal, A. (2013). Retinoprotective effects of Moringa oleifera via antioxidant, anti-inflammatory, and anti-angiogenic mechanisms in streptozotocin-induced diabetic rats. Journal of Ocular Pharmacology and Therapeutics, 29, 419-426. https://doi.org/10.1089/jop.2012.0089

Kumaran, A. and Karunakaran, R.J. (2007). In vitro antioxidant activities of methanol extracts of five Phyllanthus species from India. LWT- Food Science and Technology, 40(2), 344-352. https:// doi.org/10.1016/j.lwt.2005.09.011

Leone, A., Fiorillo, G., Criscuoli, F., Ravasenghi, S., Santagostini, L., Fico, G., Spadafranca, A., Battezzati, A., Schiraldi, A. and Pozzi, F. (2015). Nutritional characterization and phenolic profiling of Moringa oleifera leaves grown in Chad, Sahrawi Refugee Camps, and Haiti. International Journal of Molecular Sciences, 16(8), 18923-18937. https:// doi.org/10.3390/ijms160818923

Long, J., Liu, C., Sun, L., Gao, H. and Liu, J. (2009). Neuronal mitochondrial toxicity of malondialdehyde: inhibitory effects on respiratory function and enzyme activities in rat brain mitochondria. Neurochemical Research, 34, 786794. https://doi.org/10.1007/s1 1064-008-9882-7

Manguro, L.O.A. and Lemmen, P. (2007). Phenolics of Moringa oleifera leaves. Natural Product Research, 21(1), 56-68. https:// doi.org/10.1080/14786410601035811 
Miyoshi, N., Takabayashi, S., Osawa, T. and Nakamura, Y. (2004). Benzyl isothiocyanate inhibits excessive superoxide generation in inflammatory leukocytes: implication for prevention against inflammationrelated carcinogenesis. Carcinogenesis, 25(4), 567575. https://doi.org/10.1093/carcin/bgh051

Mohanty, M., Mohanty, S., Bhuyan, S.K. and Bhuyan, R. (2020). Phytoperspective of Moringa oleifera for oral health care: An innovative ethnomedicinal approach. Phytotherapy Research. [Accepted]. https://doi.org/10.1002/ptr.6896

Mridha, M. (2015). Prospects of moringa cultivation in Saudi Arabia. Journal of Applied Environmental and Biological Sciences, 5(3), 1-1.

Naeem, S., M. Ali and Mahmood, A. (2012). Optimization of extraction conditions for the extraction of phenolic compounds from Moringa oleifera leaves. Pakistan Journal of Pharmaceutical Sciences, 25, 535-541.

Noda, Y., Kneyuki, T., Igarashi, K., Mori, A. and Packer, L. (2000). Antioxidant activity of nasunin, an anthocyanin in eggplant peels. Toxicology, 148(23), 119-123. https://doi.org/10.1016/S0300-483X (00)00202-X

Oboh, G., Oyeleye, S.I., Akintemi, O.A. and Olasehinde, T.A. (2018). Moringa oleifera supplemented diet modulates nootropic-related biomolecules in the brain of STZ-induced diabetic rats treated with acarbose. Metabolic Brain Disease, 33, 457-466. https://doi.org/10.1007/s11011-018-0198-2

Ohkawa, H., Ohishi, N. and Yagi, K. (1979). Assay for lipid peroxides in animal tissues by thiobarbituric acid reaction. Analytical Biochemistry, 95(2), 351358. https://doi.org/10.1016/0003-2697(79)90738-3

Olayaki, L.A., Irekpita, J.E., Yakubu, M.T. and Ojo, O.O. (2015). Methanolic extract of Moringa oleifera leaves improves glucose tolerance, glycogen synthesis and lipid metabolism in alloxan-induced diabetic rats. Journal of Basic and Clinical Physiology and Pharmacology, 26(6), 585-593. https://doi.org/10.1515/jbcpp-2014-0129

Omodanisi, E., Aboua, Y. and Oguntibeju, O. (2017). Assessment of the anti-hyperglycaemic, antiinflammatory and antioxidant activities of the methanol extract of Moringa oleifera in diabetesinduced nephrotoxic male wistar rats. Molecules, 22 (4), 439. https://doi.org/10.3390/molecules22040439

Paula, P.C., Sousa, D.O., Oliveira, J.T., Carvalho, A.F., Alves, B.G., Pereira, M.L., Farias, D.F., Viana, M.P., Santos, F.A., Morais, T.C. and Vasconcelos, I.M. (2017). A protein isolate from Moringa oleifera leaves has hypoglycemic and antioxidant effects in
Alloxan-Induced diabetic mice. Molecules, 22(2), 271 .https://doi.org/10.3390/molecules22020271

Rouanet, J.-M., Décordé, K., Del Rio, D., Auger, C., Borges, G., Cristol, J.-P., Lean, M.E. and Crozier, A. (2010). Berry juices, teas, antioxidants and the prevention of atherosclerosis in hamsters. Food Chemistry, 118(2), 266-271. https://doi.org/10.1016/ j.foodchem.2009.04.116

Saini, R., Manoj, P., Shetty, N., Srinivasan, K. and Giridhar, P. (2016). Relative bioavailability of folate from the traditional food plant Moringa oleifera L. as evaluated in a rat model. Journal of Food Science and Technology, 53, 511-520. https:// doi.org/10.1007/s13197-015-1828-x

Saini, R., Prashanth, K.H., Shetty N. and Giridhar, P. (2014a). Elicitors, SA and MJ enhance carotenoids and tocopherol biosynthesis and expression of antioxidant related genes in Moringa oleifera Lam. leaves. Acta Physiologiae Plantarum, 36, 26952704. https://doi.org/10.1007/s11738-014-1640-7

Saini, R., Shetty, N., Prakash, M. and Giridhar, P. (2014b). Effect of dehydration methods on retention of carotenoids, tocopherols, ascorbic acid and antioxidant activity in Moringa oleifera leaves and preparation of a RTE product. Journal of Food Science and Technology, 51, 2176-2182. https:// doi.org/10.1007/s13197-014-1264-3

Silva, C.R., Simoni, J.A., Collins, C.H. and Volpe, P.L. (1999). Ascorbic acid as a standard for iodometric titrations. An analytical experiment for general chemistry. Journal of Chemical Education, 76, 1421. https://doi.org/10.1021/ed076p1421

Steel, R.G., Torrie, J.H. and Dickey, D.A. (1997). Principles and procedures of statistics: A biological approach. $3^{\text {rd }}$ ed. New York: McGraw-Hil.

Suvarna, K.S., Layton, C. and Bancroft, J.D. (2018). Bancroft's Theory and Practice of Histological Techniques. $8^{\text {th }}$ ed. USA: Elsevier. https:// doi.org/10.1016/C2015-0-00143-5

Tang, Y., Choi, E.J., Han, W.C., Oh, M., Kim, J., Hwang, J.Y., Park, P.-J., Moon, S.H., Kim, Y.S. and Kim, E.-K. (2017). Moringa oleifera from Cambodia ameliorates oxidative stress, hyperglycemia, and kidney dysfunction in type 2 diabetic mice. Journal of Medicinal Food, 20, 502-510. https:// doi.org/10.1089/jmf.2016.3792

Teixeira, E.M.B., Carvalho, M.R.B., Neves, V.A.,. Silva, M.A and Arantes-Pereira, L. (2014). Chemical characteristics and fractionation of proteins from Moringa oleifera Lam. leaves. Food Chemistry, 147, 51-54.

https://doi.org/10.1016/ 
Toma, A., Makonnen, E., Mekonnen, Y., Debella, A. and Adisakwattana, S. (2015). Antidiabetic activities of aqueous ethanol and n-butanol fraction of Moringa stenopetala leaves in streptozotocininduced diabetic rats. BMC Complementary and Alternative Medicine, 15, 242. https:// doi.org/10.1186/s12906-015-0779-0

Tuorkey, M.J. (2016). Effects of Moringa oleifera aqueous leaf extract in alloxan-induced diabetic mice. Interventional Medicine and Applied Science, 8(3), 109-117. https:// doi.org/10.1556/1646.8.2016.3.7

Villarruel-López, A., López-de la Mora, D., VázquezPaulino, O., Puebla-Mora, A., Torres-Vitela, M.R., Guerrero-Quiroz, L. and Nuño, K. (2018). Effect of Moringa oleifera consumption on diabetic rats. BMC Complementary and Alternative Medicine, 18, 127. https://doi.org/10.1186/s12906-018-2180-2

Weaver, D. and Finke, M. (2003). The relationship between the use of sugar content information on nutrition labels and the consumption of added sugars. Food Policy, 28(3), 213-219 .https:// doi.org/10.1016/S0306-9192(03)00028-9

WHO. (2017). Global report on diabetes. Germany: World Health Organization.

Yuan, G.F., Sun, B., Yuan, J. and Wang, Q. (2009). Effects of different cooking methods on healthpromoting compounds of broccoli. Journal of Zheijang University SCIENCE B, 10, 580. https:// doi.org/10.1631/jzus.B0920051

Zhang, D. and Hamauzu, Y. (2004). Phenolics, ascorbic acid, carotenoids and antioxidant activity of broccoli and their changes during conventional and microwave cooking. Food Chemistry, 88(4), 503509. https://doi.org/10.1016/

j.foodchem.2004.01.065 